\title{
„Visszatérni vidékre” - Hallgatói vidékképek kvalitatív megközelítésben
}

\section{„Return to the countryside” - A qualitative approach of students' opinions about rural life.}

\author{
K. Dajnoki ${ }^{1}$, Gy. N. Szabados², G. Kulcsár ${ }^{3}$, P. M. Kőmíves, É. Bácsné Bába ${ }^{5}$ \\ ${ }^{1}$ Debreceni Egyetem Gazdaságtudományi Kar Vezetés- és Szervezéstudományi Intézet \\ ${ }^{2}$ Debreceni Egyetem Gazdaságtudományi Kar Vezetés- és Szervezéstudományi Intézet \\ ${ }^{3}$ Debreceni Egyetem Ihrig Károly Gazdálkodás- és Szervezéstudományok Doktori Iskola \\ ${ }^{4}$ Debreceni Egyetem Gazdaságtudományi Kar Vezetés- és Szervezéstudományi Intézet \\ ${ }^{5}$ Debreceni Egyetem Gazdaságtudományi Kar Vidékfejlesztés, Turizmus- és Sportmenedzsment Intézet
}

\begin{abstract}
A publikáció elkészítését a EFOP-3.6.2-16-2017-00003 Sport- Rekreációs és Egészséggazdasági Kooperációs Kutatóhálózat létrehozása projekt támogatta. A projekt az Európai Unió támogatásával, az Európai Szociális Alap társfinanszírozásával valósult meg
\end{abstract}

\begin{abstract}
Absztrakt. Napjaink legérdekesebb szakszociológiai kutatásainak egyikét a vidék sajátosságainak feltárása képzi. Ezen belül kiemelt jelentőséggel bír a vidék életképessége és lakosság megtartó képessége, melynek igen fontos pillére, hogy a fiatalok helyben maradjanak vagy vissza akarjanak oda térni, és képesek legyenek a helyi fejlódéshez minél hatékonyabban hozzájárulni. Ebben sokféle tényezô játszik szerepet, így például a munkahely, a környezeti és szociális tényezôk, vagy épp a szabadidôs lehetőségek és a sportindíttatás is. Jelen kutatásunkban többek között arra kerestük a választ, hogy a kvalitatív felmérésben résztvevő felsőoktatási hallgatók hogyan vélekednek a hazai vidékről, annak előnyeirôl és hátrányairól, a benne rejlő lehetőségekről, emellett vizsgáltuk azon tényezôket is, amelyek közrejátszhatnak abban, hogy a válaszadók - feladva korábbi lakhelyüket - a nagyvárosban maradás mellett döntenek, illetve melyek lehetnek azok, amik visszatéríthetik óket vidékre. Végül, de nem utolsó sorban egy igen érdekes témát, a megkérdezettek vidéki elithez való viszonyát vettük górcső alá.
\end{abstract}

Abstract. Nowadays, the research of rural areas' specific features is one of the most interesting part of sociology. Within these studies the rural areas ability for survival and to retain forms an important basis. A pillar of these, that the youth from rural areas become sufficiently motivated to stay at or to return to their homeland and be able to redound development. We were looking for answers, that how university students, who participated in our current research are thinking about the hungarian countryside, in their opinion what are it's advantages and disadvantages and it's possible potentials. In addition, we examined those factors, which are contributing to that respondents who are studying in large cities want to stay there, but at the same time we wanted to explore the opposite factors, those that make tudents to return to the countryside. Last, but not least we investigated a very interesting topic, the relations between the respondents and the rural elite. 


\section{Bevezetés}

Az elvándorlás a hazai vidékről kortárs problémának tekinthető, és ez szoros összefüggésben van a területi egyenlőtlenségekkel. Valuch (2005:50-51) szerint „a területi egyenlőtlenségek megléte nem feltétlenül negatív jelenség (...), ugyanakkor a gazdasági tényezők mellett a politikának, az infrastrukturális és kulturális ellátottságnak is jelentős szerepe van (...) a területi egyenlőtlenségek akkor kívánnak korrekciót, ha olyan tartós hatásokkal járnak, melyek a helyi társadalom szerkezetét tartósan torzítják, esélyeit diszkriminatív módon rontják, így társadalmi hátrányokat hoznak létre és tartanak fenn. Nem kérdéses, hogy a helyi társadalmak azon képessége, hogy megtartsa, vagy pedig odavonzza a fiatal, munkaképes munkavállalókat, igen fontos sajátossága.” A társadalom egyes csoportjai ugyanis Valuch (2005:51) szerint „ösztönösen törekszenek a különböző típusú területi egyenlőtlenségek korrekciójára", azaz például a jobb lakhatási körülmények, a kereseti viszonyok, de akár az előbb említett politikai, infrastrukturális és kulturális változók is jelentős szereppel bírhatnak a népességmegőrző potenciál tekintetében. Így a fiatalok is az értékrendjüknek megfelelő elképzeléseik alapján változtathatnak településtípust, azaz költöznek be- vagy ki egy településről.

$\mathrm{Az}$ a település, amelyik valamilyen módon nem törekszik a fiatalság megtartására, mind foglalkoztatási, mind demográfiai, de kulturális, szociális illetve egyéb szempontok alapján problémás helyzetben találhatja magát, ráadásul az elindult folyamatok visszafordítása sokszor már nem is lehetséges. A vidék fenntartható létezésének egyik kulcsfontosságú feltétele a lakossági életkörülmények kiszámítható alakulása, amelynek egyik alapja a megfelelő, képzettségi struktúrához is illeszkedő munkahelyek elérhetősége (Harangi-Rákos - Szabó, 2012). Az ismertetett problémák nem ritkák az ország keleti részében, sőt sokszor nem is csak a komplex hátrányokkal szembenéző településeken. Így például Nyírbátor, a multinacionális szervezetekkel betelepített ipari parkkal rendelkező nyírségi város saját aktuális településfejlesztési stratégiája ír arról, hogy annak ellenére, hogy „a hasonló nagyságrendű és elhelyezkedésű városokhoz képest számos előnyt tud biztosítani lakosai számára, mégis folyamatos elvándorlás tapasztalható (2001 és 2013 között a lakónépesség száma mintegy 10\%-al csökkent), ami elsősorban a fiatal, magasabb iskolai végzettséggel rendelkező fiatalokat érinti." (www.nyirbator.hu). Érdekesség, hogy az említett dokumentum szerint 2015 januárjában 1065 fő álláskeresőt tartottak nyilván, miközben a település több nagyobb cége is munkaerőhiánytól szenvedett. A munkerőszükséglet alapvetően két területen jelentkezik, a szaktudást igénylő, illetve a betanított, végzettséget nem igénylő munkakörökben, de mindkét területen nagy létszámban. Nyilvánvalóan adja magát, hogy ha a helyi munkaerőt nem tudják beilleszteni, úgy más területekről kell azt odavonzani, ám kétséges, hogy csupán a munkahelykínálat szolgálhat-e egyedüli vonzerőként és megtartó erőként a fiatalok számára, vagy ahhoz valamivel többre lenne szükség. Egy, az adott problémát fókuszba helyező kutatás kvantitatív eredményeit egy másik cikkünk tartalmazza (bővebben lásd: Kőmíves et al., 2018), ezúttal inkább a miértekre, a hogyanokra választ kereső kvalitatív kutatással igyekeztünk a probléma alaposabb megértésére törekedni.

Napjainkban a hazai kutatások esetében - különösen érvényes ez a hazai doktori iskolákban végzett doktorandusz kutatásokra - kétféle módszertani megközelítés tűnik elfogadottnak. Az egyik a szekunder forrásokra, tartalmakra épített másodelemző munka, a másik a primer adatbázisokra alapozott úgynevezett „survey” vizsgálat. Sajnálatosan még manapság is viszonylag alacsonynak 
mondható a kvalitatív jellegű kutatások átvihetősége, a vidékkutatások terén ugyanakkor úgy tűnik, hogy igenis van létjogosultságuk. Ezt támasztja alá Csurgó (2013) város környéki vidékről készült munkája is, melyben a vidékkutatásokhoz kapcsolódóan specifikus módszertani áttekintést is ad. Különböző tudományágak jellemző kutatásmódszertani vizsgálatai és a társszerzőségi hálózatok elemzési is olyan új kutatási aspektusokat nyit meg (Popp et al., 2018), amelyek a vidékkutatásban is relevánsak lehetnek.

\section{Vidékkutatás kvalitatív módon}

Csurgó (2013:143) imént említett írásának alapját 113 félig strukturált interjú képezte, melyek „hozzájárulhatnak a vidéki tér egy sajátos típusa, a város környéki vidéken zajló folyamatok megértéséhez”. Indoklása szerint „az interjús módszer mellett az szólt, hogy a nemzetközi szakirodalomban is döntően kvalitatív, és azon belül is interjús módszerek segítségével kutatják a vidékreprezentációt”, továbbá „a város környéki vidék folyamatainak, valamint a kvantitatív vizsgálatok eredményeinek értelmezéséhez, szükséges feltáró jellegü, a mélyebb összefüggésekre fókuszáló kvalitatív vizsgálatokat is végezni" (Csurgó, 2013:143). A szerző a módszertani lehetőségek közül elsődlegesen az interjúkat, valamint az esettanulmányt emeli ki; kutatásunk alkalmával mi is ennek megfelelően igyekeztünk alkalmazni a kvalitatív megközelítést. Az interjús módszer kritikájaként meg lehet fogalmazni annak lassúságát, személyes interjú esetén költségességét, továbbá körülményességét is. Ez utóbbi körülmény mindenek előtt arra vonatkozik, hogy az interjú készítését gyakorta nem egy kutató végzi, hanem több interjúztató, akik olykor eltérő módon, stílusban vagy eljárásrend követése mellett veszik fel az adatokat, ami a végeredmény érvényességére is kihathat. Ugyanakkor azt is ki kell emelni, hogy az interjú személyes jellege azt is lehetővé teszi, hogy az egyes részterületeket mélyebben is feltárjuk a vizsgálat során, illetve magát a kérdéssort is megfelelő rugalmassággal kezeljük. Természetesen minden olyan eset, amikor az interjúztató eltér az eredeti kérdéssortól, nehezebben összevethetővé teszi az interjú után létrejövő információkat (Kothari, 2004).

Ezek közül a kevésbé strukturált megkérdezésre alapozott kvalitatív adatokat érdemes egy további módszerrel, a tartalomelemzéssel összefüggésbe hozni.

A tartalomelemzés a II. világháborútól kezdve vált önálló kvalitatív kutatási módszerré. Móré (2010:2) értelmezésében „a tartalomelemzés eredetileg annak a felismerésnek a jegyében fogant, hogy ha elegendően sok textus áll rendelkezésre, akkor ezek bizonyos elemeit megszámlálva a különbözö szövegek között értelmes összehasonlítások tehetők". Antal (1976) szerint tartalomelemzésnek nevezhető minden olyan kutatási megközelítés, melynek során közleményekből, szöveges adatokból az azokban előforduló törvényszerűen visszatérő sajátságok alapján módszeres és objektív eljárással olyan következtetéseket vonunk le. Ezek sajátossága, hogy bizonyos tartalmak a közleményekben nyíltan kimondva nincsenek, de az üzenet megszerkesztettségének, azaz kódolásának módjából kiolvashatók s esetleg más eszközökkel, más módon nyert adatok segítségével megerősíthetők, igazolhatók.

A tartalomelemzés területén számos eljárás, szakaszolás ismeretes, ennek fázisai Móré (2010) szerint a következők: 
- A forrás(ok) kiválasztása.

- A dokumentumok kiválasztása.

- Az írásbeli szöveg kvantifikálhatóvá, mérhetővé, elemezhetővé alakítása.

- A szimbólumok, szavak kategóriákba sorolása.

- Ezt követi a cikkek újbóli átolvasása. Ekkor végezzük a kategóriák előfordulásának kódolását és a gyakoriságok képzését (gyakorisági táblázat készítése az előfordulások számlálásával).

- Végül az értékelés, melyben a mennyiségi eredmények értelmezése, magyarázata, az összefüggések feltárása történik meg.

Az irodalmi ajánlás (Antal, 1976) alapján a tartalomelemzéshez tehát úgynevezett kódolásra van szükség. Ez nem más, mint a vizsgálat során kapott szövegekben, állításokban, megjegyzésekben előforduló szavak, kifejezések nagyobb, összefoglaló kategóriákba való összevonása. Ezt követően két dolgot érhetünk el:

- Egyrészt az egyes változók előfordulását rangsorolva feltárhatjuk azok fontossági sorrendjét, így a vizsgált változók értékmérőjét kapjuk a vizsgált kérdéskörben (pl. mennyire fontos a kultúra, vagy a munkalehetőségek, mint lehetséges változók a vidékképzet bemutatásakor).

- Másrészt - bár ezt az irodalmak nem írják le konkrétan - az egyes változók attribútumai olyan módon is értelmezhetők, hogy milyen lehet például a vidéki elit megítélése (pozitív, semleges, negatív). Így nem csupán az egyes változó előfordulási gyakorisága, ezáltal annak relatív jelentősége, de azok minősítésével a változó megítélése is mélyebb lehet (pl. feltárhatjuk, hogy a vidéki kultúra elsőssorban milyen, azaz pozitív, semleges, vagy épp negatív módon jelenik meg a megkérdezettek vidékképében).

A kódoláshoz először tehát kategóriákra, minősítésükhöz pedig egyszerű attribútumokra van szükségünk (pozitív, semleges és negatív említés). Ezt követően az előfordulási gyakoriságot mérünk, majd ez alapján tudunk következtetéseket megállapítani. Esetünkben a kategórialista készítésekor a főbb vizsgálati területek megítélése további kihívásokat jelentett, ugyanis azok különbözősége nem tette lehetővé a teljes kvalitatív adatbázisra vonatkozó egységes kategória-, változó- és kódrendszer elkészítését. Móré (2010:12) szerint a szöveg többszöri olvasása során kialakított kategóriák definiálása tűnik célszerűnek, mivel a „tartalomelemzés megbízhatósága és érvényessége a jól megalkotott kategóriákon múlik, a találomra felépített kategóriák érdektelen, vagy alacsony minőségú kutatási eredményre vezetnek".

\section{A vizsgálat eredményeinek bemutatása}

A kutatás a korábban általunk elkészített „Hallgatói vidékkép” strukturált kérdőív kiegészítő részeként 4 fő fejezetre tagolódott (Saját vizsgálatok, 2017):

- A hazai vidék általános megítélése.

- A vidékelhagyás, a nagyvárosba költözés magyarázata. 
- A vidékre történő visszatérés, a helyben maradás indokai.

- A vidéki elit megítélése.

\subsection{A hazai vidék általános megítélése}

A hazai vidék megítélésével kapcsolatban 108 válasszal lehetett érdemben számolni. A kategóriák megállapításakor a Móré (2010) által említett „III. Harvard Pszichológiai Szótár” 9 kategóriájából indultunk ki. A fokozatosan feltáruló részletek miatt azonban újabb kategóriákat is kialakítottunk, így összesen 15 kategóriával számoltunk, melyek attribútumaiként negatív, semleges és pozitív említési lehetőségeket határoztunk meg. Ezt követte a 108 válasz tartalmi elemeinek kódtáblába rögzítése. Az eredményeket, a kategóriák és változók előfordulási gyakoriságát az 1. ábra szemlélteti.

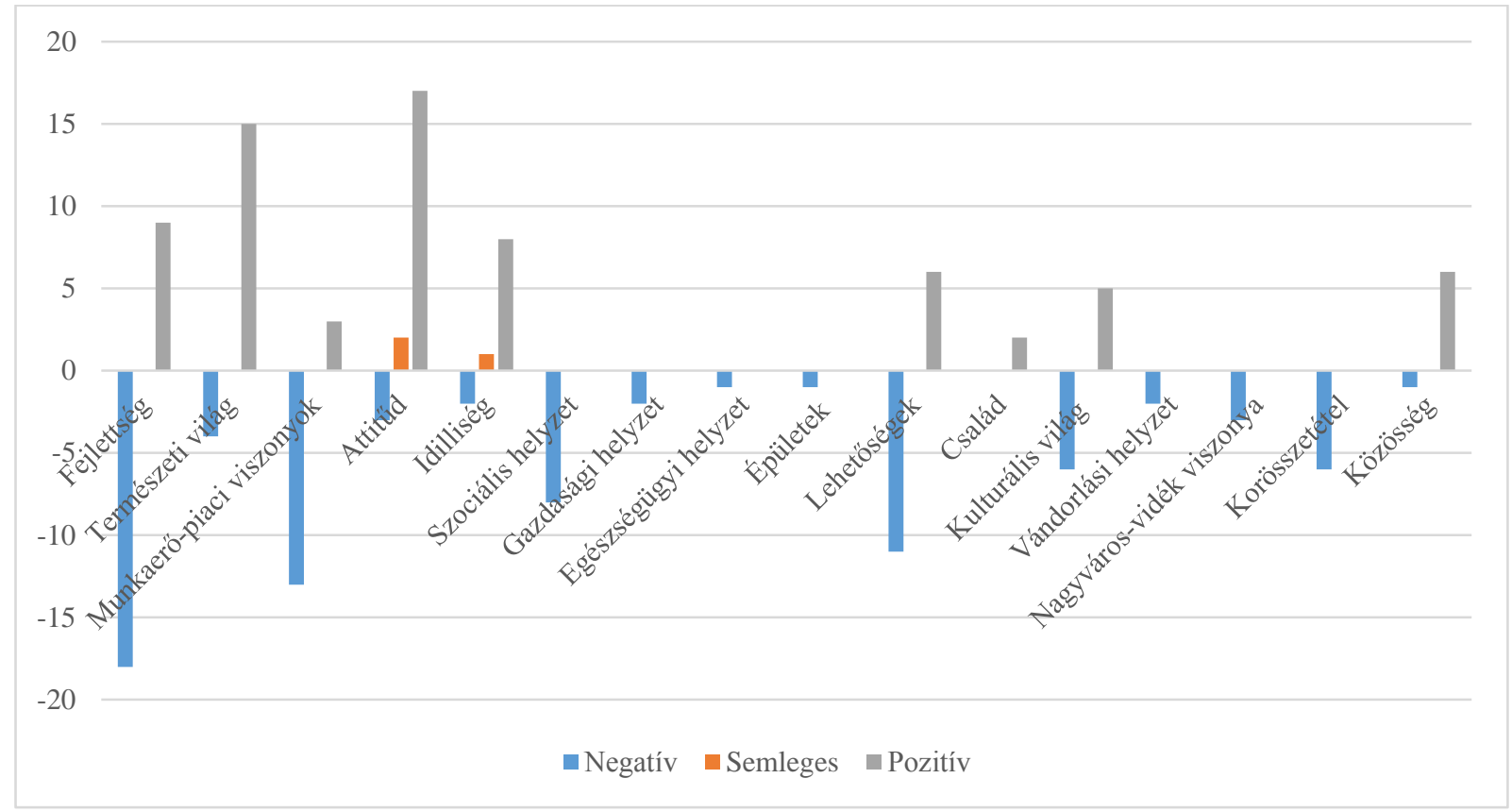

1. ábra: A hazai vidék általános megítélése.

Forrás: Saját vizsgálatok, 2017.

$\mathrm{Az}$ első érdekes eredményt a hazai vidék pozitív, semleges vagy épp negatív módon történő említésénél kaptuk. A válaszadók nagyobb arányban említettek negatív jelzőket a vidékkel kapcsolatosan (81 válasz), mint pozitív töltetűeket (71 válasz), a semlegesek gyakorisága elenyésző (3) volt, azaz a vidék megítélése inkább negatívabb kicsengésű. Ezen túlmenően az is megállapíthattuk, hogy a vidék potenciálja, előnye csupán néhány területre korlátozódik, míg a negatív válaszok sokkal több kategóriában jelentkeztek. Magyarán a kevés pozitívum néhány kategóriára korlátozódásával szemben a negatívumok áthatják a már említett kategóriák többségét hol kisebb, hol nagyobb mértékben. A többet említett kategóriák kapcsán érdemes a részleteket is áttekinteni:

(1) Többen említették a fejlettséget, pozitív értelmezésben olyan módon, hogy „fejlődő”, „folyamatosan fejlődő”, negatív megítélésben pedig „fejlesztendő”, „van hova fejlődnie”, „nem elég fejlett”, „kevés lehetőség a fejlődésre”. Itt a vidék megítélése nagyjából kétszer olyan negatív gyakoriságú, mint pozitív. 
(2) A természeti világ azon kevés kategóriák egyike, ahol a pozitív megítélések voltak többségben: 15 pozitív, 4 negatív minősítés volt. Pozitív értelemben olvashattuk, hogy „a hazai táj számomra gyönyörü”, „természeti értékekben gazdag”, „rengeteg szép vidék van”, „a tájak szépek”, a negatívak között találhattuk, hogy „szennyezett”, „lehetne több zöld terület”, „lassan minden területet beépítenek".

(3) A munkaerő-piaci viszonyok kapcsán a hátrányok a maghatározók, 3 pozitív és 13 negatív véleményt kódoltunk. A kevés pozitív előfordulás között volt a „több munkahely”, a negatív válaszok között leginkább a „nagy a munkanélküliség”, a „kevés a munkalehetőség”, az „alacsony bérek”, és a „munkahelyhiány” köszöntek vissza.

(4) Az attitűd az egyik legérdekesebb terület volt, gyakorlatilag a vidékhez való érzelmi hozzáállást figyelhettük meg az ide tartozó válaszok többségében. Úgy tűnik, hogy van egy nagyon komoly pozitív (17), kevés semleges (2) és alig valamivel több negatív vélemény a válaszok között. Pozitív módon minősített utalások voltak a „legjobb”, „meg vagyok elégedve vele”, „kellemes”, „megnyugtató”, a negatív megítélések között az „unalmas”, „lehangoló” fordultak elő. A semleges választ annak megfogalmazása miatt érdemes megemlíteni: „Vidéken az élet ugyanolyan, mint máshol, túl közel a szakadékhoz, a Mennyországtól távol”.

(5) A válaszadók szerint a hazai vidék megítélése inkább idillikus (8 pozitív válasz), mint negatív (2), mellettük 1 semleges válasz is volt. Többször visszatérő pozitív megítélésű vélemények voltak, az „idilli”, „idillikus”, míg a negatív említés ennek ellenkezőjét fogalmazta meg a „kevésbé idillikus” jelzővel.

(6) A szociális helyzet egyértelműen negatív megítélésű (8 válasszal), sem pozitív, sem semleges vélemény nem volt. Ezek között volt az „elszegényedett”, „rossz szociális helyzet”, „szegénység”, sőt egyes válaszadóknál a „vidéki társadalom leépülése zavaró” megfogalmazással is találkoztunk.

(7) Vidéken a lehetőségek visszafogottabbak, erre utalnak a válaszadók utalásai, 11 negatív és mindössze 6 pozitív megítélés kódolása után. Pozitív vélemények voltak például: „több lehetőség a boldogulásra”, „aki talpra esett, vidéken is válogathat a lehetőségek közül”, de a negatív vélemények is hangsúlyosak, mint a „korlátozottak a lehetőségek”, „kevés lehetőség”, „nincs elég lehetőség”, vagy épp a „bizonytalan jövő”.

(8) Két kategóriát érdemes még kiemelni, az egyik a kulturális viszonyok, mely a maga 6 negatív válaszával tűnt ki, mint például a „kevesebb kulturális lehetőség, „lehangoló, elmaradott a fővárostól kulturális téren”. A másik, a korösszetétel kérdése, mely kapcsán szintén a negatív vélekedések voltak túlsúlyban (6 válasz). Ilyen véleményeket olvashattunk, mint „elöregednek az ott élők”, az „idős korosztály létszáma magas”, „egy fiatal számára nem megfelelő” (Saját vizsgálatok, 2017).

\subsection{Miért költöznek a vidékelhagyók a nagyvárosokba?}

A kutatás egyik lényeges fejezetét képezte, amikor igyekeztünk minél többet megérteni abból a folyamatból, amelynek eredményeként az „egyetemvárosba” bekerülő vidéki hallgatók tanulmányaik 
végeztével már nem kívánnak visszatérni vidéki településükre, inkább a nagyvárosban maradás mellett döntenek. A már korábban említett kvantitatív kutatásból kiderült, hogy „csak a vidékröl származókat mértük fel, így 113 válaszadóval számoltunk. A megkérdezettek közel háromnegyede (87 fö) a képzés elhagyása után nem kíván visszatérni vidéki lakhelyére, szeretné azt elhagyni, mindössze 26 fó válaszolt úgy, hogy vidéken maradna" (Kőmíves et al., 2018, p. 300). A kvalitatív felmérés ezt a tendenciát tükrözi, ugyanis a 47 rögzített válaszból, a visszatérők/maradók mindössze 10-en voltak. Az elhagyók válaszainak kódolásakor az első, vidékképpel kapcsolatos kategóriából indultunk ki. Mivel a kategóriák egy része feleslegessé vált, újakat kellett képeznünk (Saját vizsgálat, 2017), az eredmények pedig az alább látható módon alakultak (2. ábra).

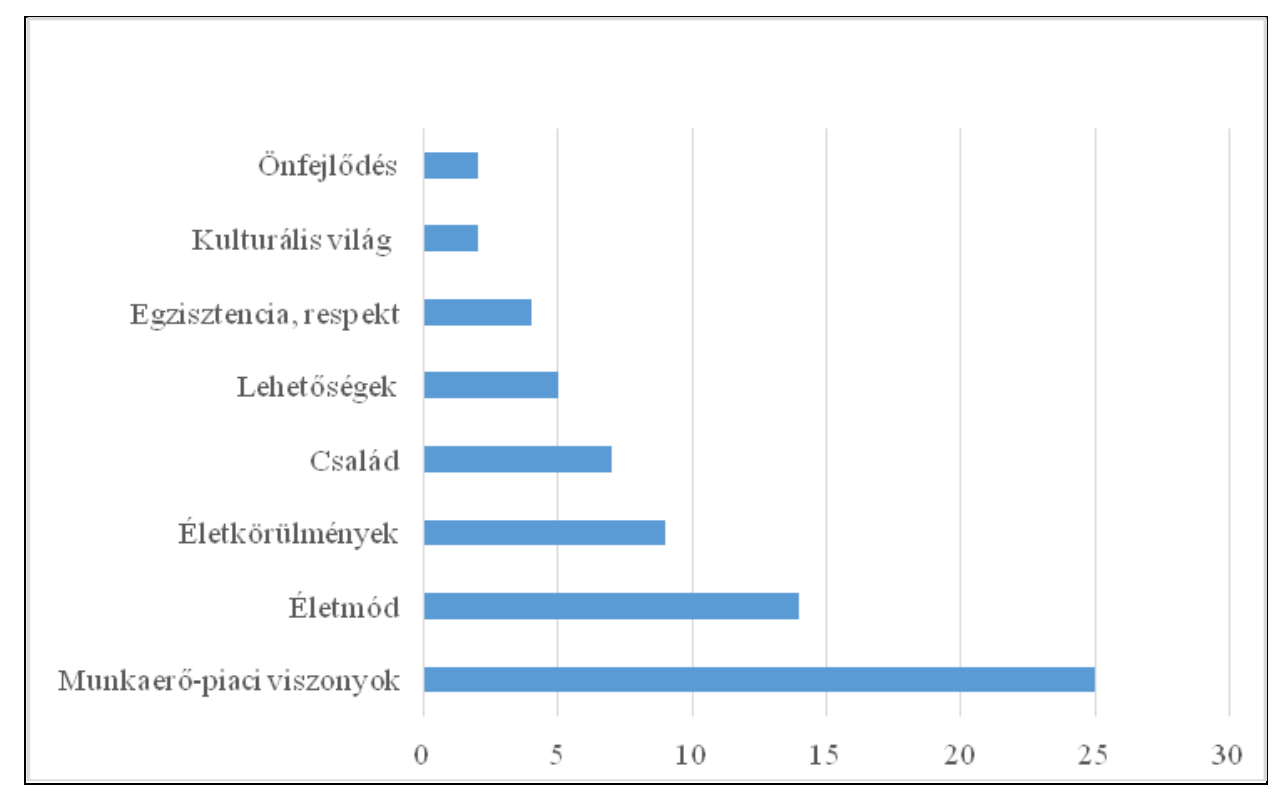

2. ábra: A nagyvárosban maradás okai.

Forrás: Saját vizsgálatok, 2017.

Az említések tekintetében nem lehet figyelmen kívül hagyni a válaszadók szerinti jobb munkaerőpiaci lehetőségeket, hiszen ez a kategória 25-ös gyakorisággal fordult elő, így fontossága a hallgatók megtartásában megkérdőjelezhetetlen. Téves ugyanakkor az a gondolkodás, amennyiben a megtartó erőt csakis a „jó munkahelyek”, a „biztos munkahely”, „több munkalehetőség”, vagy a „hosszú távú állás" biztosítja kizárólagosan, 43 említés utal arra, hogy bár a munkahely a legfontosabb, de nem az egyetlen maradást garantálni hivatott kategória. A nagyvárosi életmód szintén vonzó tényező (14 említés), ezt igazolják az alábbi jelzők is, mint a „városi élet”, a „nyüzsgő”, „pörgősebb élet”, a „több lehetőség a szabadidő kihasználására”, a „szabadidős programok”, vagy az „urbanizációval járó életstílus". Az életkörülmények szintén kiemelt fontossággal bírnak ( 9 említés), így például a „könnyebb boldogulás” és a „szép kertes ház”. A nagyobb településen jobb kilátások várhatnak a családalapítás, családi élet tekintetében is (7 említés), itt többen egyszerűen csak a „család” kifejezést használták. Úgy tűnik, hogy kisebb mértékben, de szerepe lehet a vonzerőben a lehetőségeknek (5 említés), az egzisztencia, respekt, vagyis elismertség keresésének (4), az önfejlődésnek (2), ugyanakkor a kulturális lehetőségek nem voltak meghatározók, mikor a településre költözés okait kerestük, mindössze 2 válasz érkezett, a „kulturális előnyök”, és a „mozi-színház” (Saját vizsgálatok, 2017). 


\subsection{A vidékre visszatérők maradásának magyarázata, különös tekintettel a sportra}

Viszonylag kevés vélemény kapcsolódott a vidékre való visszatéréshez, a rendelkezésre álló 10 válaszból mindösszesen 4 kategóriánál tudtunk kódolást végezni, amelyeket a 3. ábrán mutatunk be (Saját vizsgálatok, 2017).

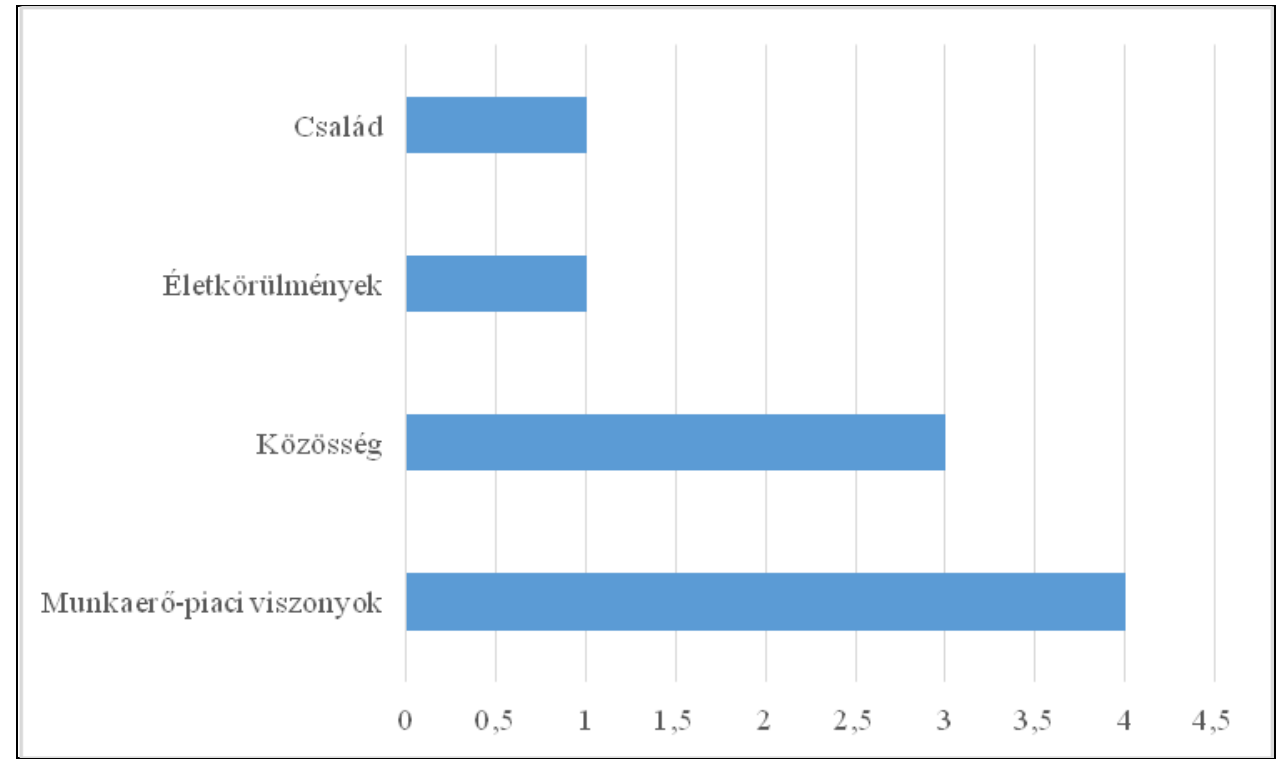

3. ábra: $A$ vidéken maradás okai.

Forrás: Saját vizsgálatok, 2017.

A kapott eredmények tekintetében úgy véljük, hogy érdemes arra a két fő kategóriára hagyatkozni, melyek a megtartó erőt képviselik. Ezek a munkaerőpiaci viszonyok és lehetőségek (4 vélemény), valamint a közösség (3). A munkaerőpiaci viszonyok tekintetében 1 fó foglalkozna „állandó munkahely keresésével", a többiek helyi vállalkozásokban látják a potenciált. Emellett a helyi közösségek ösztönzik a vidéken maradást, így a vélemények szerint a „helyi közösségi tagságot vállalnék”, valamint a „biztonságos-barátságos környezet” játszanak szerepet abban, hogy valaki visszatérjen szülőföldjére (Saját vizsgálatok, 2017).

A sport, mint sajátos motiváció a kvalitatív megközelítés eredményei alapján úgy tűnik, nem játszott szerepet a vidéken maradásban. Az eredmények arra utalnak, hogy ugyanakkor azon hallgatók esetében, akik a nagyvárosban maradás mellett döntöttek, több esetben is szerepet játszik a sporttevékenységgel kapcsolatos motiváció, mind a munkahellyel összefüggésben („sportcentrumnál helyezkedek el”, „sport világában elhelyezkedés”), valamint attól eltérően a sport, mint a „középosztálynak megfelelő szabadidős tevékenység” kapcsán is (Saját vizsgálatok, 2017). A kimutatott eredményt árnyalja, hogy korábbi felmérések szerint a felsőoktatásban tanuló hallgatók sportaktivitása sajnálatosan alacsony (Pfau - Domonkos, 2016), ugyanakkor egy korábbi kutatásban részt vevő, a Debreceni Egyetemen tanuló hallgatók közel 80\%-a vagy versenysport, vagy hobbi szintű sportolás formájában elkötelezett a testmozgás iránt (Pfau, 2015). A felsőoktatási intézményekben és 
azok székhelyén elérhető sportszolgáltatások kihatással lehetnek nemcsak a magyar, hanem akár a külföldi hallgatók intézményválasztására is (Böcskei et al., 2018).

Amikor a hallgatók arról döntenek, hogy sportolási lehetőségek miatt visszatérjenek vidékre, több körülményt kell mérlegelniük. Ezek egyike a sportinfrastruktúra és sportélet finanszírozása, amelyben a közvetlen és közvetett állami, továbbá önkormányzati támogatásoknak is nagy szerep jut (Becsky et al., 2015). A sportinfrastruktúra megléte kulcsfontosságú a sport, mint közösségi aktivitás működése szempontjából (Sárközy, 2017). Ez pedig akkor is döntő jelentőségű körülmény lehet, ha tudjuk, hogy a vidéki életnek hagyományosan részét képezték a különböző sportaktivitások, a mai városi sportklubok is vidéki testedző közösségekből alakultak ki, vagyis a sportoló vidék koncepciójának komoly történelmi háttere van (Tigyiné Pusztafalvi, 2015). Ez a jelenség visszaköszön más felmérésben is, amely kimutatta, hogy a megyeszékhelyeken élő egyetemisták körében a legnagyobb a sportokkal aktívan foglalkozók aránya. Őket a falvakban lakók követték, a legkevésbé aktívaknak pedig az egyéb városokban élők bizonyultak (Bácsné Bába et al., 2018). Mindettől függetlenül hazánkban a települési önkormányzatoknak biztosítania kell a lakosság sportolási lehetőségeit, ez pedig igaz azon településméret esetén is, ahol a felmérések a hallgatók körében a legalacsonyabb szintű sportolási elköteleződést mértéke (Szabados - Kulcsár, 2017). A települések sportfejlesztéseinek motivátora a helyi civil közösség fejlesztése és a lakosság egészségmegőrzése mellett a sport gazdasági tőkevonzó képessége is lehet (Gyömörei, 2012).

\subsection{A vidéki elit megítélése}

A vidéki elit megítélése során valamennyi megkérdezett válaszára egyaránt számítottunk, legyen az vidéki vagy megyeszékhelyi lakos. Az összesítést követően, tartalmi elemeiket tekintve 95 véleményből 85 került a rögzíthetők közé, a kimaradt 10 válasz egyik kategóriába sem volt sorolható. Az előbbiekben használt, bővített kategóriarendszer, minimális változtatásokat követően itt is alkalmazható volt. A kapott eredményeket a 4. ábra szemlélteti (Saját vizsgálatok, 2017). 


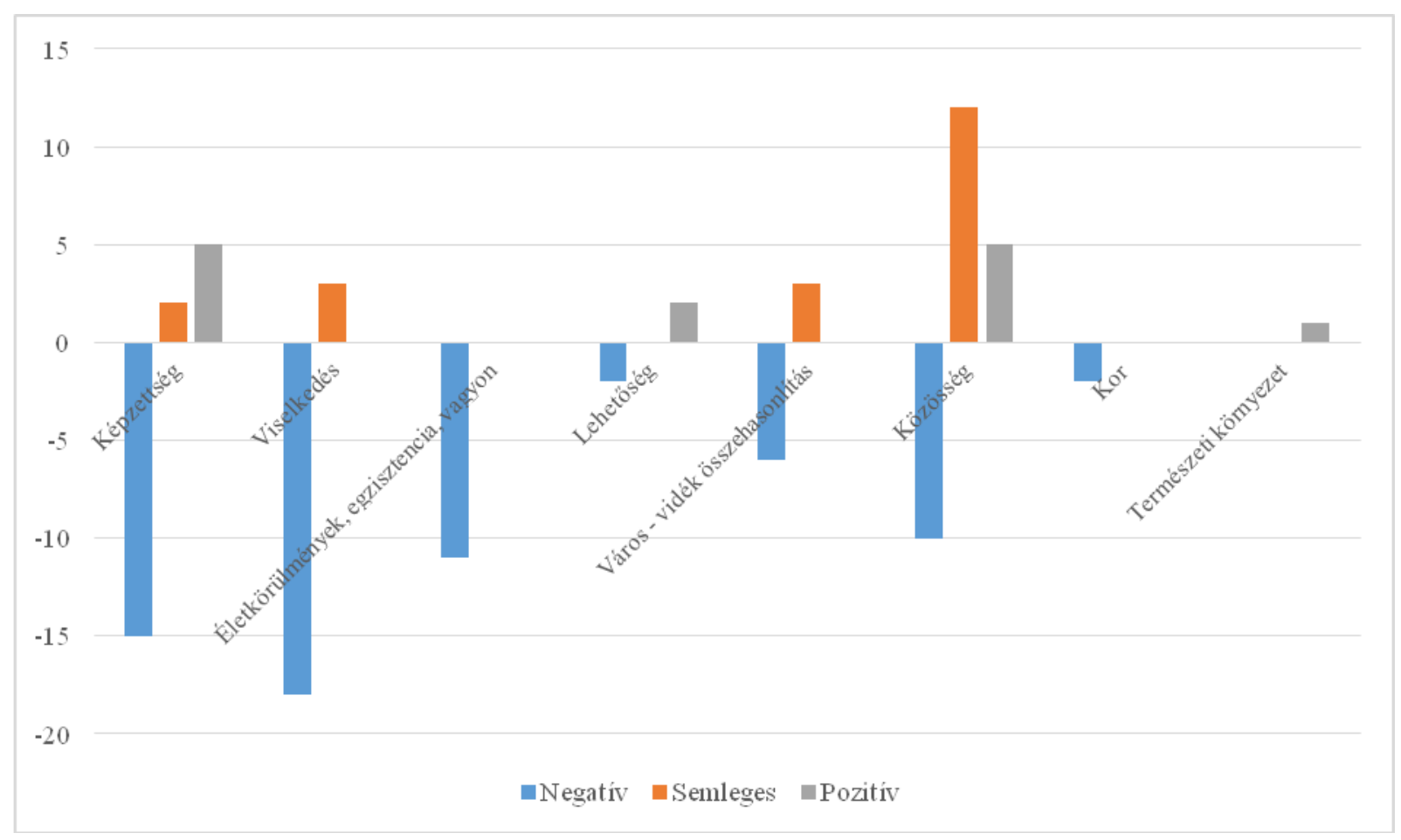

4. ábra: A vidéki elit megítélése.

Forrás: Saját vizsgálatok 2017.

(1) A vidéki elit képzettségével kapcsolatban 22 válasz állt rendelkezésünkre, ebből 5 pozitív, 2 semleges, míg 15 negatív volt. A kevés pozitív hozzászólás között a „szakképzett”, „megfelelően képzett” jelzőket olvashattuk, míg a negatív említések döntő többségében a vidéki elit „nem megfelelő”, „átlagosnál alacsonyabb szakképzettség”-éről, „aluliskolázott”ságáról szóltak, néhány válaszadó pedig még az ennél erőteljesebb fogalmazástól sem rettent meg, egyikük szerint a helyi elit képzettsége „a nullával egyenlő”.

(2) A képzettségnél is egyértelműbb volt a viselkedés kérdésének megítélése, a 21 válaszból mindössze 3-at tudtunk a semlegesek közé sorolni, a többi 18 mind a negatív kategóriába került. Itt a legtöbben az elit „nagyképű”-ségét, „előítéletes”-ségét, „beképzelt”-ségét kritizálták.

(3) A válaszadók egyöntetű véleménye volt megállapítható az elit egzisztenciájára, vagyoni helyzetére vonatkozóan is. A 11 negatív válasz arra enged következtetni, hogy jelen kérdés esetében a megkérdezettek az „anyagi javak felhalmozás”-át, az elit „saját jólétének növelés”-ét, illetve az ebből fakadó esetleges „nagyzolás”-t látja problémásnak.

(4) Bár a kapott válaszok számának szempontjából (4) kevésbé volt kiemelt jelentőségű, mégis említést érdemel, hogy a „legkiegyenlítettebb” végeredmény a lehetőségek biztosítása kérdés kapcsán született, 2 pozitív („segítőkész”) és 2 negatív („kisajátítják a kevés kínálkozó lehetőséget is") vélemény rögzítését követően.

(5) A vidéki elit megítélése során nem maradhatott ki a városi elittel való összevetés sem. A vidék - sajnos - ebben az összehasonlításban is alulmaradt, a 6 negatív említés mellett, mindössze 3 semleges vélemény „árnyalja” a már eddig sem rózsás összképet. A kapott 
válaszoknál főleg a városi elittel való - képzettségből, szakértelemből - fakadó elmaradás domborodik ki: „nem rendelkezik olyan szintű tudással, mint a városi elit”, valamint van, aki szerint a vidéki elit a „nagyvárosi elitet próbálja utánozni”, illetve volt, aki, legyen szó akár városi, akár vidéki elitről nem tett különbséget az összehasonlított csoportok között, számára „egyik sem különb a másiktól”.

(6) Az elit közösségben betöltött szerepével, arra gyakorolt hatásával kapcsolatban kaptuk a legtöbb választ, összesen 27 véleményt rögzítettünk, melyek megoszlása a következőképpen alakult: 5 pozitív, 12 semleges és 10 negatív. Többen jegyezték meg, nem csak ezen kérdés kapcsán, de a főként itt érvényesülő, vagyoni helyzetből, valamint családi és baráti kapcsolatokból fakadó „befolyás”-t, mely számos esetben bizonyulhat rendkívüli jelentőségűnek, különösen, amikor kisebb méretű településekről beszélünk. Sokuk a „vidéki eliten belül abszolút megosztottságot lát”, közöttük vannak akik „igyekeznek javítani településük helyzetén”, néha erőn felül próbálnak „a fejlődés fő irányítói” lenni. A semlegesek táborát a helyi társadalomtól, a település ügyeitől „elszigetelődött”, „visszavonult” elit képezi, és sajnálatosan megtalálhatók azok a „kerékkötők” is, akik, a már említett befolyásuk, hatalmuk birtokában „csírájában fojtanak el bármilyen jellegű fejlesztési törekvést”, amely akár kis mértékben is megbolygatná addigi zavartalan életüket, a berögződött mindennapi mechanizmusokat.

(7) Végül, de nem utolsó sorban még két kategóriáról tehetünk említést, ezek pedig a vidéki elit életkorával, illetve az elit természeti környezettel való kapcsolatával, hozzáállásával foglalkozott. Előbbihez 2 negatív, utóbbihoz 1 pozitív választ tudtunk felvezetni (Saját vizsgálatok, 2017).

\section{3. Összegzés}

Az eddigi eredményeket értékelve elmondhatjuk, hogy a kvalitatív adatok alapján kapott vidékkép szerint, egy viszonylagosan leegyszerűsített megközelítésben, a hazai vidék fejletlenebb a nagyvároshoz képest, hányatottabb munkaerőpiaci körülményekkel, rosszabb szociális helyzettel és visszafogottabb lehetőségekkel áthatott, kulturálisan elmaradottabb és öregedő társadalommal rendelkezik, ugyanakkor természeti környezete jobb, idillikusabb, mélyebben szerethető.

A következő két kategóriát (elhagyók, visszatérők kérdésköre) vizsgálva úgy tűnik, hogy a nagyvárosban maradás oka, elsősorban, de nem kizárólagosan a jobb munkaerőpiaci viszonyokkal van összefüggésben, ugyanis a városi életmód, az életkörülmények, az ottani élet biztosította lehetőségek, mind a család a helyben tartásban játszanak kétség kívül kiemelkedő szerepet. Abban, hogy mi térítheti vissza a válaszadókat vidékre, a kevés válasz alapján bizonytalanok vagyunk, ám a munkaerőpiaci érvényesülés és a közösségek szerepe itt sem hanyagolható el.

A megkérdezettek vidéki elithez való, döntően negatív hozzáállásának miértjeire próbáltunk fényt deríteni. Ennek okai rendkívül szerteágazók, azonban valamennyi fontosabb kategória esetében tetten érhetők voltak, legyen szó akár a helyi elit képzettségéről, viselkedéséről, vagy közösségben betöltött 
szerepéről. Ezek mellett a városi elittel szembeni összehasonítás során a vidéki elit további gyengeségei is megmutatkoztak.

Végezetül rövid összegzésként azt állapíthatjuk meg, hogy szinte valamennyi kérdésnél csupán néhány válaszadó esetében találkoztunk pozitív vagy semleges említésekkel, de ezek is inkább csak „szépségtapaszként” szolgáltak a korántsem hízelgő eredmények bizonyos - inkább kis - mértékű elfedésére, palástolására.

\section{Hivatkozások}

[1] L. Antal (1976) A tartalomelemzés alapjai. Magvető Kiadó, Budapest

[2] É. Bácsné Bába - V. Fenyves - Gy. Szabados - K. Pető - Z. Bács - K. Dajnoki (2018) Sport Involvement Analysis in Hungary, in the North Great Plain Region. Sustainability, 10, 1629. p. 20.

[3] A. Becsky - I. Dékán Tamásné Orbán - Z. Bács - A. Herczeg A. (2015) Financin and operating questions of sports facilities. Applied Studies in Agribusiness and Commerce - APSTRACT, 9. évfolyam, 1-2. lapszám. pp. 5-8.

[4] E. Böcskei - Z. Bács - B. Kovács - T. Tarnóczi - V. Fenyves (2018) Intézményi szolgáltatásokról a külföldi hallgatók szemével - mitôl lesz egy intézmény multikulturális? International Journal of Engineering and Management Sciences, 3. évfolyam, 4. lapszám. pp. 343-363.

[5] B. Csurgó (2013) Vidéken lakni és vidéken élni - A városból vidékre költözók hatása a vidék átalakulására: A város környéki vidék. Argumentum Kiadó, Budapest

[6] T. Gyömörei (2012) Magyarországi „sportvárosok” sportfinanszírozási rendszereinek összehasonlító elemzése. E-CONOM, 1. évfolyam, 1. lapszám. pp. 12-23.

[7] M. Harangi-Rákos - G. Szabó (2012) The economic and social role of private farm sin Hungarian agriculture. Applied Studies in Agribusiness and Commerce - APSTRACT, Vol. 6, No. 5. pp. 33-41.

[8] C. R. Kothari (2004) Research Methodology. Methods \& Techniques. Second Revised Edition. New Age International Publishers, New Delhi.

[9] P. M. Kőmíves- Gy. N. Szabados - G. Kulcsár - É. Bácsné Bába - V. Fenyves - K. Dajnoki (2018) „Visszatérni vidékre”. A sport megtartó ereje. International Journal of Engineering and Management Sciences, Vol. 3, No. 4. pp. 292-307.

[10] M. Móré (2010) A tartalomelemzés, mint szakdolgozatírásban alkalmazható kutatási módszer. In: Kovácsné Bakosi Éva (szerk.): Társadalomtudományi tanulmányok III. DE Gyermeknevelési és Felnőttképzési Kar, Hajdúböszörmény

[11] C. Pfau - Sz. Domonkos (2016) Szabadidôsport a felsőoktatásban. Taylor - Gazdálkodás- és Szervezéstudományi Folyóirat, 8. évfolyam, 2. lapszám. pp. 111-117.

[12] C. Pfau (2015) Analysis of the leisure sport activities in University of Debrecen. Apllied Studies in Agribusiness and Commerce - APSTRACT, 9. évfolyam, 1-2. lapszám. pp. 75-80.

[13] J. Popp - P. Balogh - J. Oláh - S. Kot - M. Harangi-Rákos - P. Lengyel (2018) Social Network Analysis of Scientific Articles Published by Food Policy. Sustainability, 10(3), Paper 577. p. 20.

[14] T. Sárközy (2017) A sport mint nemzetstratégiai ágazat. Polgári Szemle, 13. évfolyam, 4-6. lapszám. pp. 143-159.

[15] Gy. Szabados - G. Kulcsár (2017) Vidéki civilek - vidéki forrásteremtési lehetôségek. Taylor Gazdálkodás- és Szervezéstudományi Folyóirat, 9. évfolyam, 2. lapszám. pp. 23-30. 
[16] H. Tigyiné Pusztafalvi (2015) A sport szerepe a társadalmi kohézió és integráció terén. In: Laczkó T. - Rétsági E. (szerk.): A sport társadalmi aspektusai. Pécsi Tudományegyetem Egészségtudományi Kar, Pécs. pp. 41-50.

[17] T. Valuch (2005) Magyarország társadalomtörténete a XX. század második felében. Osiris Kiadó, Budapest.

Internetes források:

[18] Nyírbátor Város Integrált $\quad$ Településfejlesztési $\quad$ Stratégiája. http://www.nyirbator.hu/files/_nyirbatorvaros/download_files/760/NyirbatorITS20150527.p df (2017.10.24.) 